Keio J. Med. 26: 1-18, 1977

\title{
ERYTHROPOIESIS IN VITRO
}

\author{
JUNZO KANEKO* \\ Division of Hematology-Oncology, Department of Medicine, \\ UCLA School of Medicine, Los Angeles, California, U.S.A.
}

(Received for publication November 26, 1976)

\begin{abstract}
Various culture systems are now available to study erythropoiesis in vitro. These include suspension and cloning culture techniques. Suspension culture techniques are frequently used for studying biochemical changes in erythroid cells, while cloning culture techniques are suited for investigating the nature of erythroid stem cells. Some aspects of human erythropoiesis will be clarified by employing new methods such as the Marbrook diffusion chamber technique.
\end{abstract}

\section{INTRODUCTION}

Erythropoiesis has been studied using a number of in vivo and in vitro techniques. These studies have clarified many aspects of erythropoiesis-among them, the existence of erythropoietin as the major humoral regulator of erythropoiesis, and concepts surrounding erythroid stem cell proliferation and maturation., ${ }^{1,2}$ Certain biochemical changes in target cells induced by erythropoietin have been found $^{3,4}$ but the site and mode of action of this hormone are poorly understood. ${ }^{5}$ Also, relatively little is known of the factors controlling pluripotent stem cell differentiation. The introduction of reliable in vitro techniques for assessing erythropoiesis has led to changes in our concepts of the pathogenesis of certain human erythropoietic disorders.

The purpose of this communication is to review the use of in vitro culture systems in the study of erythropoiesis and to discuss some insights obtained from recent studies.

\footnotetext{
* Present Address: Hematology Section, Department of Internal Medicine, School of Medicine, Keio University, Tokyo.
} 


\section{ESTABLISHED IN VIVO TECHNIQUES}

\section{ERC (erythropoietin-responsive cell)}

The ERC can be defined as the cell which precedes the earliest recognizable erythroblast but differentiates into the erythroid cell line. ${ }^{1}$ This concept was introduced by Gurney et al. in 1962 when they reported a method to study erythroid stem cell kinetics. ${ }^{6}$ In this method, irradiated mice were used as test animals. The mice were previously made polycythemic by hypertransfusion in order to suppress endogenous erythropoiesis. At varying times after irradiation, exythropoietin was injected into test animals. Forty-eight hours after the injection of erythropoietin, ${ }^{59} \mathrm{Fe}$ was administered intravenously. Seventy-two hours after the injection of ${ }^{59} \mathrm{Fe}$, the animal were sacrificed and the erythropoietic response was assessed by the percentage of ${ }^{59} \mathrm{Fe}$ incorporated into newly formed red blood cells.

In general, suppression of erythropoiesis by hypertransfusion is sufficiently complete that no erythroblasts are seen in the spleen of the normal recipient mouse. ${ }^{7}$ After an injection of erythropoietin, pronormoblasts and normoblasts appear in the spleen within 24 and 72 hours respectively. A similar phenomenon is observed when the spleen of the polycythemic mouse is exposed to erythropoietin in vitro. ${ }^{8}$

Mice rendered polycythemic by hypertransfusion or extreme hypoxia are sensitive to exogenous erythropoietin and have little active erythropoiesis.9,10 The bioassay of erythropoietin or erythropoietic activity of test materials is conveniently performed with these animals. ${ }^{1}$

\section{2. $C F U-S$ (colony-forming unit, spleen)}

In 1961 Till and McCulloch described an in vivo colony-forming technique in which macroscopically visible spleen colonies were observed when a lethally irradiated mouse was injected with isologous bone marrow cells. ${ }^{11}$ Mixed colonies of erythroid, granulocytic, and megakaryocytic cells were found in the spleen and the clonal origin of the colonies was demonstrated later by Becker, et al. ${ }^{12}$ The spleen colony assay may be used to quantify the pluripotent stem cell in murine hematopoietic tissues.

\section{HISTORICAL PERSPECTIVE OF IN VITRO CULTURE METHODS}

In 1910, Carrel and Burrows first reported the culture of bone marrow, utilizing fibrin clots. ${ }^{13}$ In 1937 a simple method of suspension culture was described by Osgood and Brownlee in which medium supplemented with human 
cord serum was used. ${ }^{14}$ In 1958 Matoth and co-workers reported a culture method in which bone marrow cells were suspended in plasma clots and the medium containing test material was added to the clots in culture tubes. ${ }^{15}$ The erythrostimulatory effect of sera from anoxic patients on human marrow was shown by counting the number of early and intermediate normoblasts. In 1959 Reisner developed an organ culture system for bone marrow explants. ${ }^{16}$ A glass cylinder, sealed at one end by a cover glass, was used as a culture vessel. When human bone marrow was cultured on a tantalum gauze in this glass well, the continuous outflow of hematopoietic cells into the surrounding medium was observed microscopically over five months. Erythroblasts were seen during the first month. In the same year, Berman and Powsner reported a method of suspension culture in a roller tube. ${ }^{17}$

From the beginning of the 1960's, biochemical studies on erythroid cells started with the availability of crude erythropoietin preparations. ${ }^{18-23}$

Long-term hemoglobin synthesis in vitro has been reported by $\mathrm{Kraus},{ }^{24}$ Hall and Motulsky ${ }^{25}$ in culture systems maintained at a low temperature $\left(27^{\circ} \mathrm{C}\right)$, then by Gabuzda and Silver, ${ }^{26}$ and recently by Wood ${ }^{27}$ in cultures containing added erythropoietin.

In 1971, colony formation by erythroid cells in vitro was demonstrated by Stephenson et al. in a plasma clot culture system using mouse fetal liver. ${ }^{28}$ The cell which gave rise to an erythroid colony in vitro was designated "CFU-E" to discriminate it from granulocytic and monocytic colony-forming units in vitro (CFU-C). In 1974, Iscove et al. reported that erythroid colony formation was also observed in culture containing methylcellulose as a supporting matrix. ${ }^{29}$ Both techniques need added erythropoietin to allow the growth of erythroid colonies in vitro. ${ }^{28,29}$

Liquid culture systems which have been developed in recent years by Wood ${ }^{30}$ and Golde et al.s1 will be dealt with in detail in this article, as well as other culture systems.

\section{METHODOLOGY}

The in vitro culture methods which have been developed recently can be classified simply into two types: suspension culture systems and in vitro cloning techniques.

a. Suspension Culture Systems

1. Measurement of heme synthesis in vitro ${ }^{19,32}$

In 1963, Krantz, Gallien-Lartigue, and Goldwasser reported a culture method 
that demonstrated an increased rate of heme synthesis in rat bone marrow cells incubated with erythropoietin. ${ }^{19}$

This short-term suspension culture (for up to 72 hours) is performed in Petri dishes where the cells are suspended in NCTC-109 medium supplemented with autologous or human serum (and, later, fetal calf serum) with or without erythropoietin. Four hours before the termination of culture, ${ }^{59} \mathrm{Fe}$, preincubated with autologous serum to bind it to transferrin, is added to the plates. After the pulse with ${ }^{59} \mathrm{Fe}$, the cells are lysed and hydrochloric acid is added to dissociate heme from the globin. Heme is extracted into cyclohexanone or other solvent and the radioactivity of ${ }^{59} \mathrm{Fe}$ incorporated into heme is counted in a gamma counter. The result is expressed as the rate of increased heme synthesis compared with control cultures.

This system is probably the prototype of all the other culture methods to study biochemical aspects of differentiating erythroid cells in the presence of erythropoietin.

2. Measurement of hemoglobin synthesis in vitro

Although the radioactivity of heme determined by the method of Krantz et $a .^{19}$ is considered to be equivalent to that of hemoglobin, ${ }^{5,33}$ heme and globin synthesis in erythroid cells can be studied separately, utilizing other isotope tracers such as radioactive glycine, $\Delta$-aminolevulinic acid ( $\triangle \mathrm{ALA}$ ), leucine, and valine. The incorporation of these tracers into heme or globin can be analyzed precisely by the extraction of heme and by electrophoretic or chromatographic separation of hemoglobins and globin chains.

3. Measurement of the uptake of radioactive iron, glucosamine, uridine, and thymidine

The radioactivity of these tracers incorporated into intracellular nonheme iron, ${ }^{23}$ the stroma, ${ }^{34} \mathrm{RNA}^{20}$ and $\mathrm{DNA}^{21,22}$ of erythroid cells, respectively, is measured after utilizing appropriate techniques for precipitation and extraction. ${ }^{3} \mathrm{H}$-thymidine incorporation is often expressed as the percentage of labelled erythroid cells on autoradiography. ${ }^{35}$

4. Other suspension culture techniques

1. Wood described a method of human bone marrow culture in Leighton tubes containing medium supplemented with 50\% AB serum and added erythropoietin..$^{30}$ The medium is changed every 48 hours and erythropoietin was added to the new medium. In this culture system, normoblasts at all stages of maturation are observed even after 10 days in culture. ${ }^{3} \mathrm{H}$-thymidine is used for autoradiography.

2. Golde et al. described a culture method that supports human erythro- 
poiesis in vitro for periods up to two weeks. ${ }^{31}$ The Marbrook diffusion chamber employed in this method consists of a glass tube closed at one end by a dialysis membrane mounted in an Erlenmeyer flask. A cell suspension $\left(3 \times 10^{6}\right.$ cells in $1 \mathrm{ml}$ of medium) is incubated in the glass tube with added erythropoietin. The flask is filled with $50 \mathrm{ml}$ of McCoy's $5 \mathrm{~A}$ medium supplemented with $20 \%$ fetal calf serum. The medium is not changed during culture. Proliferation and maturation of nucleated erythroblasts are assessed by trypan blue viability determinations, differential counts, and ${ }^{3} \mathrm{H}$-thymidine labelling indices.

\section{b. In Vitro Cloning Techniques}

\section{CFU-E (colony-forming unit, erythroid)}

1. Plasma clot technique $28,36,37$

One $\mathrm{ml}$ of cell suspension is added to a Petri dish containing $0.1 \mathrm{ml}$ of citrated bovine plasma and the mixture is allowed to clot. The medium contains added erythropoietin and other additional requirements. Cultures are incubated at $37^{\circ} \mathrm{C}$ in humidified $5 \% \mathrm{CO}_{2}$ in air, usually for 2 days (murine cells) or 7-9 days (human cells). After incubation, the plasma clots are removed from the culture dishes and spread out on a glass slide for staining and counting. Colonies of eight or more cells showing a positive hemoglobin reaction are scored.

In 1974, McLeod et al. reported an improved plasma clot system with the use of disposable microtiter plates. ${ }^{36}$ The required amount of the medium per well is one-tenth of that in the original method.

2. Methylcellulose culture techniques ${ }^{29}$

Murine or human hematopoietic cells are mixed thoroughly in a tube containing erythropoietin and $\alpha$ medium supplemented with $0.8 \%$ methylcellulose, $30 \%$ fetal calf serum, and $1 \%$ bovine serum albumin. A total volume of $1 \mathrm{ml}$ is placed in a Petri dish $(35 \mathrm{~mm})$. Erythroid colonies containing eight or more cells are counted directly under an inverted microscope after the same periods of incubation as mentioned above for a plasma clot culture. Erythroid colonies are easily distinguished from granulocytic colonies in cultures of murine cells, but in the case of human cells the discrimination of colonies may be difficult. Therefore, if necessary, the adherent cells are removed before plating. When desired, individual colonies may be removed, then fixed and stained on a glass slide.

\section{BFU-E (erythropoietic burst-forming unit)}

Recently, Axelrad et al. observed, using the modified plasma clot culture system, the formation of "bursts" in cultures of mouse bone marrow exposed to high concentrations of erythropoietin for four days. ${ }^{38}$ These consisted of a large 
number of erythroid cells which appeared after six days of culture and reached a plateau at 7-9 days. The cell which gave rise to a "burst" was named BFU-E.

On the other hand, using the methylcellulose culture system, Iscove and Sieber reported that the addition of a large amount of purified erythropoietin in a single dose also resulted in the formation of macroscopic erythroid colonies by the tenth day in culture of mouse bone marrow. ${ }^{39}$

\section{c. Significance of CFU-E and BFU-E}

It has been suggested that there are several stages of differentiation between CFU-S and CFU-E ${ }^{40,41}$ and the relationship of these two components is not as close as that of CFU-S and CFU-C,42 but rather CFU-E may be the same population as ERC in vivo. ${ }^{41}$ Hypertransfusion decreases the number of CFU-E but not BFU-E. ${ }^{38}$ BFU-E has a slower sedimentation velocity than CFU-E. ${ }^{38}$

These findings suggest that BFU-E may be a precursor of CFU-E in vivo, although further studies will be needed to characterize its properties.

It has been reported that the addition of sulfhydryl compounds increases plating efficiency markedly in a methylcellulose culture of mouse bone marrow. ${ }^{39}$ However, the effect seems to depend on whether the cells require these compounds or not. ${ }^{43}$

\section{INSIGHTS GAINED FROM IN VITRO STUDIES}

\section{Normal erythropoiesis}

It is now obvious that erythropoietin is the primary regulator of erythropoiesis in higher organisms. ${ }^{1}$ The production of this hormone is stimulated under conditions that create tissue hypoxia and is suppressed under opposite conditions. Whether the hormone exists in renal tissue in an inactive form binding to a lipid inhibitor or exists as erythrogenin which catalyzes the conversion of a plasma globulin precursor into erythropoietin is controversial. ${ }^{1,44}$

Many other hormones and substances have been known to modulate erythropoiesis in vivo. ${ }^{1,45,46}$ Among them, androgens have been investigated intensively because of their therapeutic value in the treatment of certain human anemias.

Androgens and certain $5 \beta-\mathrm{H}$ steroids are known to exert an effect on erythropoiesis in two different ways: stimulation of erythropoietin production and a direct effect on hematopoietic tissue. ${ }^{47-54}$

Stimulatory effects of androgens on erythropoiesis have been reported utilizing in vitro culture techniques. Reisner observed that testosterone stimulated erythropoiesis using an organ culture technique. ${ }^{55}$ Stimulation of DNA synthesis by testosterone was demonstrated in suspension cultures of human bone marrow 
using ${ }^{3} \mathrm{H}$-thymidine. ${ }^{56}$ Increased rates of heme ${ }^{49,53}$ and globin ${ }^{53}$ synthesis by $5 \beta-\mathrm{H}$ steroids were shown utilizing the method of Krantz et al. and a similar suspension culture method. Increased synthesis of an RNA which had a similar sedimentation coefficient to globin messenger RNA was reported in cultures of human fetal liver cells incubated with testosterone for five hours, followed by a one-hour pulse with radioactive uridine. ${ }^{57}$ These reports imply that $5 \beta-\mathrm{H}$ steroids actually modulate the proliferation or maturation of erythroid cells in vivo.

While the number of CFU-E has been reported to increase under the influence of androgens, ${ }^{58-60}$ an effect of some steroids with $5 \beta$ configuration on CFU-S was also suggested by Byron using the ${ }^{3} \mathrm{H}$-thymidine suicide technique. ${ }^{61} \mathrm{His}$ data suggested that these steroids may trigger CFU-S into cycle or shorten cell cycle times. This idea has been supported by other investigators. Moriyama and Fisher reported that the stimulatory effect of testosterone administered to rabbits was suppressed by busulfan which is known to block the inflow of CFU-S into ERC. ${ }^{50}$ Singer and Adamson recently reported that etiocholanolone-stimulated CFU-E had little sensitivity to a suicidal dose of ${ }^{3} \mathrm{H}$-thymidine while erythropoietin- and fluoxymesterone-stimulated CFU-E were very sensitive. ${ }^{62}$ This finding suggests that different steroids may act on different stem cell subpopulations.

Prostaglandins and cyclic nucleotides have been known to stimulate erythropoiesis in vivo. ${ }^{63-69}$ The effect is probably due to stimulation of erythropoietin production or some erythropoietin-dependent processes because nephrectomy ${ }^{69}$ or the injection of anti-erythropoietin ${ }^{63,66,67,69}$ blocks the effects of these substances. It has been reported that prostaglandins augment the effect of exythropoietin in vitro by increasing the rate of heme synthesis and glucosamine incorporation into the stroma. ${ }^{64}$ Cyclic AMP and dibutylic cyclic AMP (dbcAMP) have been reported to increase the rate of $\triangle$ ALA synthesis in rat bone marrow cells. ${ }^{70}$ Heme synthesis has also been shown to be stimulated by dbcAMP in cultures of human bone marrow. ${ }^{71}$ These data suggest that the stimulation of erythropoiesis in vivo by these substances may be in part due to direct effects on hematopoietic tissue.

\section{Erythropoietin action}

Erythropoietin is a glycoprotein hormone with a molecular weight of about 46,000. ${ }^{3}$ Erythropoietin acts on erythropoietin-responsive cells (ERC) to induce proliferation and differentiation along the erythroid cell line, but it also acts on early and possibly even late erythroblasts to accelerate their maturation.,72 An effect of the hormone on the microvascular system of hematopoietic tissue has also been suggested by studies using in vivo microscopic techniques. ${ }^{73}$

Biochemical changes induced by erythropoietin in ERC have been investigated using in vitro culture systems. ${ }^{3}$ The earliest event is a synthesis of a 
type of RNA (150S) restricted to the nucleus. Following increased synthesis of DNA, about six hours ( 10 hours in cells from plethoric animals) after erythropoietin is added to culture, an increase in hemoglobin synthesis becomes evident. These findings have been derived mainly from cultures of rat bone marrow ${ }^{3}$ but fetal liver of rodents has also been used frequently in this area of study since fetal liver contains relatively high percentages of erythroid precursors capable of responding to erythropoietin in vitro. ${ }^{74}$ In cultures of mouse fetal liver, it was reported that addition of erythropoietin caused an increase in DNA synthesis within 20 minutes and in RNA and hemoglobin synthesis in two hours. ${ }^{22}$ Terada et al. reported that there was a 6- to 10-fold increase in globin messenger RNA activity by 10 hours after erythropoietin was added to cultures of mouse fetal liver. ${ }^{75}$

Since many hormones are known to act via specific receptors, ${ }^{76}$ it is most likely that erythropoietin requires receptors to initiate its action. Surface protein receptors to this hormone were postulated by Chang et al. ${ }^{77}$ Erythropoietin action may not be dependent on the cyclic AMP system. ${ }^{78}$ However, it was reported recently that erythropoietin raised intracellular concentrations of cyclic GMP in a time- and dose-dependent manner, while cyclic AMP content did not change in cultures of rat fetal liver. ${ }^{79}$

An active cytoplasmic fraction of a protein nature capable of stimulating RNA synthesis in marrow cell nuclei was recently extracted from erythropoietintreated rat marrow cells by Chang and Goldwasser. ${ }^{80}$

\section{Regulation of hemoglobin synthesis}

Hemoglobin synthesis is the primary function of differentiating erythroid cells. Both proliferation and maturation of erythroid cells are triggered by erythropoietin, but there is no clear evidence that this hormone increases the rate of hemoglobin synthesis per erythroid cell.1,4 Recently, Glass et al. reported that erythropoietin stimulated hemoglobin synthesis of murine erythroid cells which were fractionated by velocity sedimentation, at all stages of maturation. ${ }^{72}$

The "hemoglobin switch" that is seen in certain sheep and goats under erythropoietic stress has been studied in recent years by using new in vitro culture techniques. ${ }^{81-83}$ Utilizing the modified method of Krantz et al., Adamson and Stamatoyannopoulous showed direct evidence that erythropoietin mediates the hemoglobin $\mathrm{A} \rightarrow \mathrm{C}$ switch of sheep. ${ }^{81}$ They observed that hemoglobin $\mathrm{C}$ was synthesized preferentially in the bone marrow culture of sheep with hemoglobin A, stimulated with erythropoietin in a dose-dependent fashion and this effect was blocked by anti-erythropoietin. Barker et al. reported that in short-term suspension culture in the presence of erythropoietin, goat bone marrow began 
to synthesize $\beta^{\mathrm{c}}$ chain after 48 to 72 hours when $\beta^{\mathrm{A}}$ chain synthesis was falling off. 82 Barker and co-workers also cultured goat bone marrow in the plasma clot system of McLeod et al. ${ }^{83}$ They observed that higher concentrations of erythropoietin were needed to induce $\beta^{\mathrm{c}}$ globin synthesis as compared with the amounts of the hormone required to grow erythroid colonies.

The culture method of Wood has been used to study hemoglobin synthesis in vitro. ${ }^{27,84}$ It was shown by Shchory and Weatherall that $\alpha, \beta$, and $\lambda$ chain synthesis of human fetal liver were maintained for 12 days with a constant ratio of $\alpha / \beta+\lambda$ up to eight days. ${ }^{84}$ Wood reported that adult bone marrow continued to synthesize hemoglobin $A$ for up to 12 days in the presence of erythropoietin while hemoglobin $\mathrm{F}$ synthesis in vitro by adult marrow was not demonstrated. ${ }^{27}$

The precise mechanisms controlling differential gene expression in erythroid cells will be investigated further utilizing in vitro culture techniques.

\section{Human erythropoietic disorders}

1. Pure red cell aplasia

The autoimmune nature of this disease has been suggested by many investigators. ${ }^{85-88}$ By utilizing the method of Krantz et al., an inhibitor of heme synthesis has been found in the plasma of patients with pure red all aplasia. ${ }^{86,88}$ An anti-erythropoietin-like substance reported by Jepsen and Lowenstein in the plasma of a patient with panmyelopathy ${ }^{89}$ may be found in some cases of pure red cell aplasia as Krantz indicated. ${ }^{90}$ In fact, a serum IgG antibody to circulating erythropoietin was demonstrated recently by Peschle et al. in one patient with this disease. ${ }^{91}$

2. Aplastic anemia

This disease has been postulated to be due to an abnormality of the pluripotent stem cell or an altered microenvironment surrounding hemopoietic cells because aplastic anemia is characterized by pancytopenia of varying degrees of severity ${ }^{92}$ The defects of genetically anemic $W / W^{v}$ and $S 1 / S 1^{d}$ mice exist in the stem cell and the microenvironment respectively, ${ }^{1}$ although in man there is no clear evidence for a microenvironmental defect as a cause of aplastic anemia.

By utilizing the culture system of Krantz et al., two types of response were observed in patients with bone marrow failure. ${ }^{93}$ Some marrows responded normally with an increased rate of heme synthesis while other marrows did not respond at all. However, recovery of responsiveness was observed in the nonresponsive group when the patients improved clinically. Subnormal responses to erythropoietin were also reported in patients with aplastic anemia utilizing the same culture system. ${ }^{94}$ No erythroid colonies were found to grow in plasma clot cultures of bone marrow from six patients with congenital and acquired aplastic 
anemia. $^{95}$

These observations do not explain the nature of this disease because no heme synthesis or colony formation could occur with either a markedly decreased number of erythroid progenitor cells or a complete block of their responsiveness to the hormone.

In patients with Diamond-Blackfan syndrome it was reported that erythroid colonies grew even when the bone marrows had less than $1 \%$ identifiable erythroblasts although the numbers of CFU-E were below normal.96 CFU-E were normal in patients treated with prednisone. The authors suggested that decreased responsiveness of erythroid progenitor cells to erythropoietin can be modified by corticosteroids but clinically the response to corticosteroids is known to vary in this disease. ${ }^{97}$ Therefore, in some cases another explanation may be required. In connection with this, it was demonstrated by Golde et al. that corticosteroids augmented the action of erythropoietin and increased the number of CFU-E in cultures of mouse fetal liver and adult bone marrow of both mouse and man.98

\section{Other anemias}

The anemia of chronic renal failure is caused by many factors such as hemolysis, bleeding tendency, and impaired production of erythropoietin.99 An inhibitor of heme synthesis was found in the plasma of uremic rabbits by using the method of Krantz et al. ${ }^{100}$ The increased number of CFU-E in the bone marrow of uremic rabbits and normal response of the CFU-E to erythropoietin in vitro were reported by Moriyama and Fisher. ${ }^{101}$ These findings may have bearing on the treatment of uremic patients. The suppression of erythropoiesis in these patients is partially ameliorated by androgens. Perhaps a technique can be developed to remove the plasma inhibitor. It was reported that testosterone enanthate increased erythrocyte 2,3-diphosphoglycerate in patients with chronic renal failure on hemodialysis. ${ }^{102}$ This effect results in enhancement of oxygen supply to the tissues by shifting the oxygen dissociation curve to the right. The pathogenesis of anemias associated with neoplasmas, inflammation, and other chronic diseases may be clarified by in vitro studies.

\section{Polycythemia vera}

In contrast to secondary polycythemia, augmented erythropoiesis in polycythemia vera is not associated with increased plasma or urinary erythropoietin levels.103 Although the autonomous nature of this disorder has been postulated,104,105 it has been known that erythropoiesis in polycythemia vera is still under a humoral control in vivo. ${ }^{106,107}$

Using a short-term suspension culture technique, Krantz reported that bone marrows of patients with polycythemia vera responded poorly to erythropoietin 
while a normal response in terms of heme synthesis was seen in patients in remission after busulfan therapy. ${ }^{108}$ This finding in vitro has been supported by other investigators. ${ }^{106,100}$ However, it has been demonstrated recently by Golde and Cline that polycythemic marrows responded to added erythropoietin in cultures maintained for up to 18 days in diffusion chambers.110,111 It was also shown that without added erythropoietin, erythropoiesis was more marked and prolonged as compared with normal marrows. The discrepancy in the results gained from these two different types of culture system may be explained by the difference in incubation time. In the method which Krantz employed, the cultures were harvested within 72 hours. ${ }^{108}$ On the other hand, when polycythemic marrows were cultured in the in vitro diffusion chamber system, the stimulatory effect by erythropoietin was not obvious until after three days.110,111

Prchal and Axelrad cultured polycythemic marrows in a plasma clot system in which some erythroid colonies formed without added erythropoietin. ${ }^{112}$ However the majority of CFU-E were shown to be dependent on erythropoietin. Zanjani et al. demonstrated that the "endogenous" colony formation was completely blocked by anti-erythropoietin. ${ }^{113}$ This finding suggests at least that all the CFU-E of polycythemic marrows are dependent on erythropoietin.

Myelostimulatory factors in the plasma of patients with polycythemia vera also have been investigated.114

Recently, strong evidence was presented by Adamson et al. that polycythemia vera is a clonal stem cell disorder similar to chronic myelocytic leukemia. ${ }^{115}$ Only the A-type isoenzyme of glucose-6-phosphate dehydrogenase was found in red cells, granulocytes, and platelets of two female patients with polycythemia vera who had $A$ and $B$ type isoenzyme in fibroblasts and lymphocytes.

The nature of erythroleukemia and erythroblastic crisis of chronic myelocytic leukemia may be clarified by in vitro studies. Clinical observations suggest that erythropoiesis of the former may be dependent on erythropoietin ${ }^{116,117}$ and that of the latter may not.118

\section{SUMMARY AND CONCLUSIONS}

The culture methods and insights gained from in vitro studies have been reviewed in regard to erythropoiesis.

Biochemical changes of differentiating erythroid cells have been found by employing short-term suspension culture system. Proliferative aspects of erythroid progenitor cells can be studied most readily by using in vitro cloning techniques. Some suspension culture systems which have been developed in recent years appear to be suited for studying both proliferative and maturational aspects 
of erythropoiesis.

The results obtained from in vitro studies should be cautiously interpreted because of the limitations of the culture system used.

It is hoped that in vitro culture techniques will be used more widely and frequently and that insights gained from these studies will shed light on clinical problems of human erythropoietic disorders.

\section{ACKNOWLEDGEMENTS}

The author is indebted to Dr. David W. Golde and Miss Noelle Bersch for help and advice in preparing this manuscript.

\section{REFERENCES}

1. Krantz, S. B. and Jacobson, L. O.: Erythropoietin and the Regulation of Erythropoiesis. University of Chicago Press, Chicago, Illinois, 1970

2. Lajtha, L. G.: Haemopoietic stem cells. (Annotation). Br. J. Haematol. 29: 529 535,1975

3. Goldwasser, E.: Erythropoietin and the differentiation of red blood cells. Fed. Proc. 34: 2285-2292, 1975

4. Chui, D. H. K., Djaldetti, M., Marks, P. A. and Rifkind, R. A.: Erythropoietin effects of fetal mouse erythroid cells. I. Cell population and hemoglobin synthesis. J. Cell. Biol. 51: 585-595, 1971

5. Krantz, S. B.: Recent contributions to the mechanism of action and clinical relevance of erythropoietin. (Editorial). J. Lab. Clin. Med. 82: 847-857, 1973

6. Gurney, C. W., Lajtha, L. G., and Oliver, R.: A method for investigation of stemcell kinetics. Br. J. Haematol. 8: 461-466, 1962

7. Filmanowicz, E. and Gurney, C. W.: Studies on erythropoiesis. XVI. Response to a single dose of erythropoietin in polycythemic mouse. J. Lab. Clin. Med. 57: $65-72,1961$

8. Nakao, K., Miura, Y. and Takaku, F.: In vitro effect of erythropoietin on the spleen of the polycythemic mouse I. Blood 27:646-653, 1966

9. Gurney, C. W., Wackman, N. and Filmanowicz, E.: Studies on erythropoiesis. XVII. Some quantitative aspects of the erythropoietic response to erythropoietin. Blood 17: 531-546, 1961

10. Cotes, P. M. and Bangham, D. R.: Bio-assay of erythropoietin in mice made polycythaemic by exposure to air at a reduced pressure. Nature 191: 1065-1067, 1961

11. Till, J.E. and McCulloch, E. A.: A direct measurement of the radiation sensitivity of normal mouse bone marrow cells. Rad. Res. 14: 213-222, 1961

12. Becker, A.J., McCulloch, E.A. and Till, J. E.: Cytological demonstration of the clonal nature of spleen colonies derived from transplantable mouse marrow cells. Nature 197: 452-454, 1963

13. Carrel, A. and Burrows, M. T.: Cultivation of adult tissues and organs outside of the body. J.A.M.A. 55: 1379-1381, 1910

14. Osgood, E. E. and Brownlee, I. E.: Culture of human marrow. J.A.M.A. 108: 1793-1796, 1937

15. Matoth, Y., Biezunski, N. and Szabo, G.: Effect of sera from patients with anoxia 
on the proliferative activity of human erythropoietic tissue in vitro. J. Lab. Clin. Med. $51: 420-428,1958$

16. Reisner, E. H.: Tissue culture of bone marrow. Ann. N.Y. Acad. Sci. 77: 487-500, 1959

17. Berman, L. and Powsner, E. R.: Review of methods for studying maturation of human erythroblasts in vitro: evaluation of a new method of culture of cell suspension in a clot-free medium. Blood 14: 1194-1212, 1959

18. Erslev, A.J.: Effect of erythropoietin on the uptake and utilization of iron by bone marrow cells in vitro. Proc. Soc. Exp. Biol. Med. 110: 615-620, 1962

19. Krantz, S. B., Gallien-Lartigue, O. and Goldwasser, E.: The effect of erythropoietin upon heme synthesis by marrow cells in vitro. J. Biol. Chem. 238: 40854090,1963

20. Krantz, S. B. and Goldwasser, E.: On the mechanisms of erythropoietin-induced differentiation. II. The effect on RNA synthesis. Biochem. Biophys. Acta 103: 325-332, 1965

21. Dukes, P. P.: In vitro studies on DNA synthesis of bone marrow cells stimulated by erythropoietin. Ann. N.Y. Acad. Sci. 149: 437-444, 1968

22. Paul, J. and Hunter, J.A.: Synthesis of macromolecules during induction of haemoglobin synthesis by erythropoietin. J. Mol. Biol. 42: 31-41, 1969

23. Hrinda, M. E. and Goldwasser, E.: On the mechanism of erythropoietin-induced differentiation. VI. Induced accumulation of iron by marrow cells. Biochem. Biophys. Acta 195: 165-175, 1969

24. Kraus, L. M.: Formation of different haemoglobin in tissue culture of human bone marrow treated with human deoxyribonucleic acid. Nature 192: 1055-1057, 1961

25. Hall, J. G. and Motulsky, A. G.: Production of foetal haemoglobin in marrow cultures of human adults. Nature 217: 569-571, 1968

26. Gabuzda, T. G. and Silver, R. K.: Hemoglobin and ferritin synthesis in erythroid cells in prolonged marrow cell cultures. J. Cell. Physiol. 74: 273-282, 1969

27. Wood, W. G.: Haemoglobin synthesis in suspension cultures of human bone marrow. Br. J. Haematol. 26: 451-458, 1974

28. Stephenson, J. R., Axelrad, A. A., McLeod, D. L. and Shreeve, M. M.: Induction of colonies of hemoglobin-synthesizing cells by erythropoietin in vitro. Proc. Nat. Acad. Sci. U.S.A. 68: 1542-1546, 1971

29. Iscove, N. N., Sieber, F. and Winterhalter, K. H.: Erythroid colony formation in cultures of mouse and human bone marrow: analysis of the requirement for erythropoietin by gel filtration and affinity chromatography on agarose-concanavalin A. J. Cell. Physiol. 83: 309-320, 1974

30. Wood, W. G.: Erythroid cell proliferation in human bone marrow suspension cultures. Br. J. Haematol. 26: 441-450, 1974

31. Golde, D. W., Schooley, J. C. and Cline, M. J.: Erythropoietin-stimulated proliferation of human red cell precursors in vitro. Br. J. Haematol. 28: 119-123, 1974

32. Krantz, S. B.: The effect of erythropoietin on human bone marrow cells in vitro. Life Sci. 4: 2393-2397, 1965

33. Gallien-Lartigue, O. and Goldwasser, E.: Hemoglobin synthesis in marrow cell culture: the effect of rat plasma on rat cells. Science 145:277-279, 1964

34. Dukes, P. P. and Goldwasser, E.: On the mechanism of erythropoietin-induced differentiation. III. The nature of erythropoietin action on [14 C] glucosamine incorporation by marrow cells in culture. Biochem. Biophys. Acta 108: 447-454, 1965

35. Metcalf, D. and Moore, M. A. S.: Haemopoietic Cells. North-Holland Publishing 
Co., Amsterdam, 1971

36. McLeod, D. L., Shreeve, M. M. and Axelrad, A. A.: Improved plasma culture system for production of erythrocytic colonies in vitro: quantitative assay method for CFU-E. Blood 44: 517-534, 1974

37. Tepperman, A. D., Curtis, J. E. and McCulloch, E. A.: Erythropoietic colonies in cultures of human marrow. Blood 44:659-669, 1974

38. Axelrad, A. A., McLeod, D. L., Shreeve, M. M. and Heath, D. S.: Properties of cells that produce erythrocytic colonies in vitro. In, W. A. Robinson (Ed.) Hemopoiesis in Culture. U.S. Government Printing Office, Washington, D.C., 1974, pp. 226-234

39. Iscove, N. N. and Sieber, F.: Erythroid progenitors in mouse bone marrow detected by macroscopic colony formation in culture. Exp. Hematol. 3: 32-43, 1975

40. Gregory, C. J., McCulloch, E. A. and Till, J. E.: Erythropoietic progenitors capable of colony formation in culture: state of differentiation. J. Cell. Physiol. 81: 411-420, 1973

41. Gregory, C. J., Tepperman, A. D., McCulloch, E. A. and Till, J. E.: Erythropoietic progenitors capable of colony formation in culture: response of normal and genetically anemic $\mathrm{W} / \mathrm{Wv}$ mice to manipulations of the erythron. J. Cell. Physiol. 84: 1-12, 1974

42. Wu, A. M., Siminovitch, L., Till, J. E. and McCulloch, E. A.: Evidence for a relationship between mouse hemopoietic stem cells and cells forming colonies in culture. Proc. Natl. Acad. Sci. U.S.A. 59: 1209-1215, 1968

43. Toohey, J.I.: Sulfhydryl dependence on primary explant hematopoietic cells. Inhibition of growth in vitro with vitamin $B_{12}$ compounds. Proc. Natl. Acad. Sci. U.S.A. $72: 73-77,1975$

44. Erslev, A. J.: In vitro production of erythropoietin by kidneys perfused with a serum-free solution. Blood: 44: 77-85, 1974

45. Peschle, C., Sasso, G. F., Mastroberardino, G. and Condorelli, M.: The mechanism of endocrine influences on erythropoiesis. J. Lab. Clin. Med. 78: 20-29, 1971

46. Fisher, J. W.: Erythropoietin: pharmacology, biogenesis and control of production. Pharmacol. Rev. 24: 459-508, 1972

47. Fried, W. and Gurney, C. W.: The erythropoietic-stimulating effect of androgens. Ann. N.Y. Acad. Sci. 149: 356-365, 1968

48. Naets, J. P. and Wittek, M.: The mechanism of action of androgens on erythropoiesis. Ann. N.Y. Acad. Sci. 149: 366-377, 1968

49. Necheles, T.F. and Rai, U. S.: Studies on the control of hemoglobin synthesis: the in vitro stimulating effect of a $5 \beta-\mathrm{H}$ steroid metabolite on heme formation in human bone marrow cells. Blood 34: 380-384, 1969

50. Gorshein, D. and Gardner, F. H.: Erythropoietic activity of steroid metabolites in mice. Proc. Natl. Acad. Sci. U.S.A. 65: 564-568, 1970

51. Gordon, A.S., Zanjani, E.D., Levere, R.D. and Kappas, A.: Stimulation of mammalian erythropoiesis by $5 \beta-\mathrm{H}$ steroid metabolites. Proc. Natl. Acad. Sci. U.S.A. 65 : $919-924,1970$

52. Malgor, L. A. and Fisher, J.W.: Effects of erythropoietin and testosterone on erythropoiesis in bone marrow of isolated perfused hind limbs of dogs. Acta Haematol. $43: 321-328,1970$

53. Mizoguchi, H. and Levere, R. D.: Enhancement of heme and globin synthesis in cultured human marrow by certain $5 \beta-\mathrm{H}$ steroid metabolites. J. Exp. Med. 134: 1501-1512, 1971

54. Paulo, L. G., Fink, G. D., Roh, B. L. and Fisher, J. W.: Effects of several androgens and steroid metabolites on erythropoietin production in the isolated perfused dog kidney. Blood 43: 39-47, 1974 
55. Reisner, E. H.: Tissue culture of bone marrow. II. Effect of steroid hormones on hematopoiesis in vitro. Blood 27: 460-469, 1966

56. Jacobson, W., Sidman, R. L. and Diamond, L. K.: The effect of testosterone on the uptake of tritiated thymidine by the bone marrow of children. Ann. N.Y. Acad. Sci. 149: 389-405, 1968

57. Congote, L. F. and Solomon, S.: Testosterone stimulation of a rapidly labeled, low-molecular-weight RNA fraction in human hepatic erythroid cells in culture. Proc. Natl. Acad. Sci. U.S.A. 72: 523-527, 1975

58. Moriyama, Y. and Fisher, J. W.: Effects of testosterone and erythropoietin on erythroid colony formation in rabbit bone marrow cultures. Life Sci. 15: 11811188,1974

59. Moriyama, Y. and Fisher, J. W.: Increase in erythroid colony formation in rabbits following the administration of testosterone. Proc. Soc. Exp. Biol. Med. 149: $178-180,1975$

60. Moriyama, Y. and Fisher, J. W.: Effects of testosterone and erythropoietin on erythroid colony formation in human bone marrow culture. Blood 45: 665-670, 1975

61. Byron, J. W.: Effect of steroids on the cycling of haemopoietic stem cells. Nature 228: 1204, 1970

62. Singer, J. W. and Adamson, J. W.: Steroids and hematopoiesis: different target cells for androgenic and nonandrogenic steroids. (Abstract). Clin. Res. 23: 282A, 1975

63. Schooley, J. C. and Mahlmann, L. J.: Stimulation of erythropoiesis in plethoric mice by prostaglandins and its inhibition by antierythropoietin. Proc. Soc. Exp. Biol. Med. 138: 523-525, 1971

64. Dukes, P. P.: Erythropoietic effects of prostaglandins. In, S. Bergstrom, S. Bernhard (Eds.) Advances in the Biosciences. Vol. 9. Pergamon Press-Vieweg, 1973, pp. 183-188

65. Winkert, J. and Birchette, C.: Increased RBC iron uptake after N6-2'-O-dibutyryl $3^{\prime} 5^{\prime}$-cyclic AMP (DCAMP). (Abstract). Fed. Proc. 29: 843, 1970

66. Gidari, A. S., Zanjani, E. D. and Gordon, A. S.: Stimulation of erythropoiesis by cyclic adenosine monophosphate. Life Sci. 10: 895-900, 1971

67. Schooley, J. C. and Mahlmann, L. J.: Stimulation of erythropoiesis in the plethoric mouse by cyclic-AMP and its inhibition by antierythropoietin. Proc. Soc. Exp. Biol. Med. 137: 1289-1292, 1971

68. Rodgers, G. M., Fisher, J. W. and George, W. J.: Increase in hematocrit, hemoglobin and red cell mass in normal mice after treatment with cyclic AMP. Proc. Soc. Exp. Biol. Med. 148: 380-382, 1975

69. Peschle, C., Rappaport, I. A., D'Avanzo, A., Russolillo, S., Marone, G. and Condorelli, M.: Renal mechanisms underlying cyclic AMP action on erythropoiesis. Br. J. Haematol. 25: 393-398, 1973

70. Bottomley, S. S., Whitcomb, W. H., Smithee, G. A. and Moore, M. Z.: Effect of cyclic adenosine- $3^{\prime}, 5^{\prime}$-monophosphate on bone marrow $\Delta$-aminolevulinic acid synthetase and erythrocyte iron uptake. J. Lab. Clin. Med. 77: 793-801, 1971

71. Gorshein, D. and Gardner, F. H.: The effect of steroid metabolites and cyclic AMP on iron uptake by human bone marrow cultures. (Abstract). Blood 36: 847,1970

72. Glass, J., Lavidox, L. M. and Robinson, S. H.: Studies of murine erythroid cell development. Synthesis of heme and hemoglobin. J. Cell. Biol. 65: 298-308, 1975

73. McCuskey, R. S., Meineke, H. A. and Kaplan, S. M.: Studies of the hemopoietic microenvironment. II. Effect of erythropoietin on the splenic microvasculature of polycythemic $\mathrm{CF}_{1}$ mice. Blood 39: 809-813, 1972 
74. Fantoni, A., de la Chapelle, A., Rifkind, R. A. and Marks, P. A.: Erythroid cell development in fetal mice: synthetic capacity for different proteins. J. Mol. Biol, 33: 79-91, 1968

75. Terada, M., Cantor, L., Metafora, S., Rifkind, R. A., Bank, A. and Marks, P. A.: Globin messenger RNA activity in erythroid precursor cells and the effect of erythropoietin. Proc. Natl. Acad. Sci. U.S.A. 69: 3575-3579, 1972

76. Cuatrecasas, P.: Membrane receptors. Annu. Rev. Biochem. 43: 169-214, 1974

77. Chang, S. C.-S., Sikkema, D. and Goldwasser, E.: Evidence for an erythropoietin receptor protein on rat bone marrow cells. Biochem. Biophys. Res. Commun. 57: 399-405, 1974

78. Graber, S. E., Carrillo, M. and Krantz, S. B.: Lack of effect of erythropoietin on cyclic adenosine $3^{\prime}, 5^{\prime}$-monophosphate levels in rat fetal liver cells. J. Lab. Clin. Med. 83: 288-295, 1974

79. Bomboy, J. D., Graber, S. E., Salmon, W. D. and Krantz, S. B.: Stimulation of cyclic GMP levels in rat fetal liver cells by erythropoietin. (Abstract). Clin. Res. 23: 269A, 1975

80. Chang, C. S. and Goldwasser, E.: On the mechanism of erythropoietin-induced differentiation. XII. A cytoplasmic protein mediating induced nucleus RNA synthesis. Dev. Biol. 34: 246-254, 1973

81. Adamson, J.W. and Stamatoyannopoulos, G.: Activation of hemoglobin C synthesis in sheep marrow culture. Science 180: 310-312, 1973

82. Barker, J. E., Last, J. A., Adams, S. L., Nienhuis, A.W. and Anderson, W.F.: Hemoglobin switching in sheep and goats: erythropoietin-dependent synthesis of hemoglobin $\mathrm{C}$ in goat bone-marrow cultures. Proc. Natl. Acad. Sci. U.S.A. $70: 1739-1743,1973$

83. Barker, J. E., Anderson, W. F. and Nienhuis, A. W.: Hemoglobin switching in sheep and goat. V. Effect of erythropoietin concentration on in vitro erythroid colony growth and globin synthesis. J. Cell Biol. 64: 515-527, 1975

84. Shchory, M. and Weatherall, D. J.: Haemoglobin synthesis in human fetal liver maintained in short-term tissue culture. Br. J. Haematol. 30: 9-20, 1975

85. Barnes, R. D.: Refractory anaemia with thymoma. (Letter to Editor). Lancet 2: 1464,1966

86. Krantz, S. B. and Kao, V.: Studies on red cell aplasia. II. Report of a second patient with an antibody to erythroblast nuclei and a remission after immunosuppressive therapy. Blood 34: 1-13, 1969

87. Al-Mondhiry, H., Zanjani, E. D., Spivack, M., Zalusky, R. and Gordon, A. S.: Pure red cell aplasia and thymoma: loss of serum inhibitor or erythropoiesis following thymectomy. Blood 38: 576-582, 1971

88. Zalusky, R., Zanjani, E. D., Gidari, A.S. and Ross, J.: Site of action of a serum inhibitor of erythropoiesis. J. Lab. Clin. Med. 81: 867-875, 1973

89. Jepson, J. H. and Lowenstein, L.: Panhypoplasia of the bone marrow: I. Demonstration of a plasma factor with anti-erythropoietin-like activity. Can. Med. Assoc. J. 99-101, 1968

90. Krantz, S. B.: Pure red-cell aplasia. N. Engl. J. Med. 291: 345-350, 1974

91. Peschle, C., Marmont, A. M., Marone, G. Genovese, A., Sacchetti, L. and Condorelli, M.: The IgG serum inhibitor in adult pure red cell aplasia (PRCA): assay techniques and mechanism of action. In, K. Nakao, J. W. Fisher, F. Takaku (Eds.) Erythropoiesis. Proceedings of the Fourth International Conference on Erythropoiesis. University of Tokyo Press, 1975, pp. 489-499

92. Stohlman, F., Jr.: Aplastic anemia. (Editorial). Blood 40: 282-286, 1972

93. Mizoguchi, H., Miura, Y., Takaku, F., Sassa, S., Chiba, S. and Nakao, K.: The effect of erythropoietin on human bone marrow cells in vitro. I. Studies of nine 
cases of bone marrow failure. Blood: 37: 624-633, 1971

94. Hotta, T. and Yamada, H.: In vitro response of bone marrow cells to erythropoietin in aplastic anemia. Acta Haematol. 52: 265-272, 1974

95. Freedman, M. H. and Saunders, E. F.: Variables in erythroid colony growth (CFU-E) from human marrow. (Abstract). Clin. Res. 23: 272A, 1975

96. Freedman, M. H., Amato, D. and Saunders, E. F.: Erythroid colony growth in congenital hypoplastic anemia. Presented at the Seventeenth Annual Meeting of the American Society of Hematology, Atlanta, Georgia, 1974

97. Bloom, G. E.: Disorders of bone marrow production. Pediatr. Clin. North Am. 19: $983-1008,1972$

98. Golde, D. W., Bersch, N. and Cline, M. J.: Potentiation of erythropoiesis in vitro by dexamethasone. J. Clin. Invest. 57: 57-62, 1976

99. Erslev, A.J.: Anemia of chronic renal failure, In, J.W. Williams, E. Beutler, A. J. Erslev, R. W. Rundles (Eds.) Hematology. McGraw-Hill Co., 1972, pp. 237244

100. Moriyama, Y., Rege, A. and Fisher, J. W.: Studies on an inhibitor of erythropoiesis. II. Inhibitory effects of serum from uremic rabbits on heme synthesis in rabbit bone marrow cultures. Proc. Soc. Exp. Med. 148: 94-97, 1975

101. Moriyama, Y. and Fisher, J.W.: Effects of erythropoietin in erythroid colony formation in uremic rabbit bone marrow culture. Blood 45:659-664, 1975

102. Parker, J., Beirne, G. J., Desai, J. N., Raich, P. C. and Shahidi, N. T.: Androgeninduced increase in red-cell 2,3-diphosphoglycerate. N. Engl. J. Med. 287: 381383,1972

103. Adamson, J.W.: The erythropoietin/hematocrit relationship in normal and polycythemic man-implications of marrow regulation. Blood 32: 597-609, 1968

104. Dameshek, W.: Some speculations on the myeloproliferative syndrome. (Editorial). Blood 6: $372-375,1951$

105. Gurney, C. W.: Polycythemia vera and some possible pathogenetic mechanisms. Annu. Rev. Med. 16: 169-186, 1965

106. Moriyama, Y.: Studies on regulation of erythropoiesis in polycythemia vera. Jap. J. Clin. Hematol. 10: 701-711, 1969

107. Adamson, J.W.: The regulation of erythropoiesis in polycythemia vera and related myeloproliferative disorders. In, W. J. Clark, E, B. Howard, P. L. Hackett (Eds.) Myeloproliferative Disorders in Animals and Man. U.S. Atomic Energy Commission, Washington, D.C., 1970, pp. 440-452

108. Krantz, S. B.: Response of polycythemia vera marrow to erythropoietin in vitro. J. Lab. Clin. Med. 71: 999-1012, 1968

109. Mizoguchi, H. and Miura, Y.: Studies of the pathogenesis of polycythemia vera with a special emphasis on the kinetics of hematopoietic stem cells. Jap. J. Clin. Hematol. 15: 237-242, 1974

110. Golde, D. W. and Cline, M.J.: Erythropoietin responsiveness in polycythemia vera. Br. J. Haematol. $29: 567-573,1975$

111. Golde, D. W.: Regulation of human erythropoiesis in liquid culture, In, $\mathbf{K}$. Nakao, J. W. Fisher, F. Takaku (Eds.) Erythropoiesis. Proceedings of the Fourth International Conference on Erythropoiesis. University of Tokyo Press, 1975, pp. 209-217

112. Prchal, J. F. and Axelrad, A. A.: Bone marrow responses in polycythemia vera. (Letter to Editor). N. Engl. J. Med. 290: 1382, 1974

113. Zanjani, E. D., Lutton, J. D., Goldstein, K. and Wasserman, L. R.: Endogenous erythroid colony formation by polycythemia vera (PV) bone marrow: inhibition by anti-erythropoietin. (Abstract). Clin. Res. 23: 285, 1975

114. Zanjani, E. D.: Hematopoietic factors in polycythemia vera. Semin. Hematol. 
13: $1-12,1976$

115. Adamson, J. W., Fialkow, P. J., Murphy, S., Prchal, J. F. and Steinmann, L.: Polycythemia vera: the nature of the cellular origin of the disease. (Abstract). Blood 46: 1025, 1975

116. Gabuzda, T. G., Shute, H. E. and Erslev, A. J.: Regulation of erythropoiesis in erythroleukemia. Arch. Intern. Med. 123: 60-63, 1969

117. Adamson, J. W. and Finch, C. A.: Erythropoietin and the regulation of erythropoiesis in DiGuglielmo's syndrome. Blood 36: 590-597, 1970

118. Srodes, C. H., Hyde, E. H. and Boggs, D. R.: Autonomous erythropoiesis during erythroblastic crisis of chronic myelocytic leukemia. J. Clin. Invest. 52: 512-515, 1973 